Section Editor

Robert C. Griggs, MD
Editors' Note: Dr. Chin and authors Aarli and Abramsky discuss the lack of resources but surplus of enthusiasm with regard to neurology education in sub-Saharan Africa. Dr. Chow, an anesthesiologist, referencing "Education Research: Changing practice: Residents' adoption of the atraumatic lumbar puncture needle," discusses his own educational initiative in teaching epidural insertions.

-Megan Alcauskas, MD, and Robert C. Griggs, MD

\section{WHEN IS A GLOBAL HEALTH PROGRAM GLOBAL?}

Jerome H. Chin, Berkeley, CA: Drs. Aarli and Abramsky ${ }^{1}$ highlighted the scarcity of neurology and neuroscience education in most countries of subSaharan Africa. African medical students, medical residents, and staff physicians need both bedside teaching and didactic education in clinical neurology to acquire the basic skills required to care for their neurologic patients. I have been teaching neurology on the inpatient ward of Mulago Hospital, the national referral hospital of Uganda, twice yearly for the past 4 years. I am always impressed and encouraged by the enthusiasm of the Ugandan students and residents for learning neurology during my visits. More support from leading neurology organizations and societies is needed to improve neurology training at medical schools in sub-Saharan Africa and other resourceconstrained regions of the world.

Author Response: Johan A. Aarli, Bergen, Norway; Oded Abramsky, Jerusalem: We agree with Dr. Chin that more information from leading medical schools in sub-Saharan Africa is needed to scale up clinical training in neurology. We were impressed and encouraged by the students' enthusiasm when we conducted clinical training. The key problem is the inconsistent neuroscience curricula. The World Federation of Neurology and regional neurology associations must be more active in establishing training programs in neurology at their medical schools.

C 2014 American Academy of Neurology

1. Aarli JA, Abramsky O. When is a global health program global? Neurology 2013;80:2088-2089.
EDUCATION RESEARCH: CHANGING PRACTICE: RESIDENTS' ADOPTION OF THE ATRAUMATIC LUMBAR PUNCTURE NEEDLE

Tony K.F. Chow, Melbourne: I applaud Dr. Tung's ${ }^{1}$ efforts in attempting to change her residents' practice with the goal of preventing postdural puncture headache (PDPH). Despite scientific evidence and institutional recommendations, few clinicians have adopted the use of atraumatic needles. ${ }^{2}$ In obstetric anesthesiology, the use of atraumatic needles is standard. However, PDPH occurs in epidural analgesia (18G/16G Touhy needles). Higher rates of PDPH occur during the training of new residents, despite extensive tutorials followed by 10 supervised insertions. PDPH occurs during supervision and ironically increases when residents work independently. I initiated a change by teaching epidural insertion in the elective cesarean section setting in nonlaboring parturients versus a distressed parturient in the labor ward. Fellow anesthesiologists and obstetricians criticized the approach because it added 20-30 minutes per operation. Cost-comparison studies based on the prevention of PDPH would likely show benefit to the health care system. ${ }^{3}$ Randomized trials comparing current teaching to that proposed in this WriteClick submission may provide evidence to meet core competencies standards (Accreditation Council for Graduate Medical Education). However, this type of study will not occur in my hospital due to administrative conflicts, a global dilemma that prohibits meaningful research and innovative education. ${ }^{4}$

Author Response: Christie E. Tung, Stanford, CA: I thank Dr. Chow for his interest and applaud him for making a change in his teaching practice. The incorporation and teaching of cost-effective care continues to be placed on the back burner in most academic residencies globally. ${ }^{1}$ Awareness may improve if more support is garnered from the residents for teaching methods that lead to more costeffective care. The barriers to implementation may also slowly fall with growing awareness of the rising costs of health care.

(C) 2014 American Academy of Neurology 
1. Tung CE. Education Research: changing practice: residents adoption of the atraumatic lumbar puncture needle. Neurology 2013;80:e180-e182.

2. Armon C, Evans R. Addendum to assessment: prevention of post-lumbar puncture headaches. Neurology 2005;65: 510-512.
3. Tung CE, So YT, Lanberg MG. Cost comparison between the atraumatic and cutting lumbar puncture needle. Neurology 2012;78:109-133.

4. Fuchs VR, Milstein A. The $\$ 640$ billion question: why does cost-effective care diffuse so slowly? N Engl J Med 2011; 364:1985-1987.

EDITORIAL EXPRESSION OF CONCERN: Structural and functional brain connectivity in presymptomatic familial frontotemporal dementia

With regard to the research article "Structural and functional brain connectivity in presymptomatic familial frontotemporal dementia” by Dopper et al. (Neurology ${ }^{\circledR}$ 2013;80:814-823; published ahead of print February 6, 2013), we are publishing this expression of concern to alert readers that the authors have discovered an error in the analyses that may influence the results and are planning to resolve the issue with additional studies. We are waiting for the authors to complete the reanalysis and will update readers when the results are received. 


\section{Neurology}

Education Research: Changing practice: Residents' adoption of the atraumatic lumbar
puncture needle

Tony K.F. Chow and Christie E. Tung

Neurology 2014;82;734-735

DOI 10.1212/01.wnl.0000444557.46526.8d

This information is current as of February 24, 2014

\section{Updated Information \&} Services

References

Permissions \& Licensing

Reprints including high resolution figures, can be found at: http://n.neurology.org/content/82/8/734.2.full

This article cites 4 articles, 3 of which you can access for free at: http://n.neurology.org/content/82/8/734.2.full\#ref-list-1

Information about reproducing this article in parts (figures,tables) or in its entirety can be found online at:

http://www.neurology.org/about/about_the_journal\#permissions

Information about ordering reprints can be found online:

http://n.neurology.org/subscribers/advertise

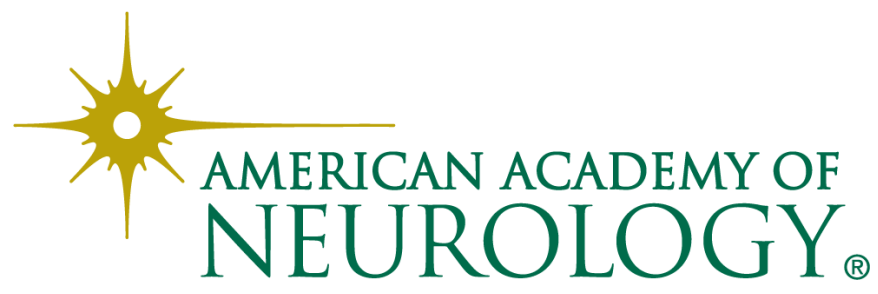

